\title{
Radviliškio rajono agronimai: Baisogalos, Radviliškio ir Šeduvos valsčių agronimų darybos linkmès
}

\author{
IILONA MICKIENE், SANDRA GAILIŪNAITE் \\ Vilniaus universiteto Kauno humanitarinis fakultetas, Muitinės g. 12, LT-44280 Kaunas \\ El. paštas: ilona.mickiene@vukhf.lt, sandra_gailiunaite@yahoo.com
}

\begin{abstract}
Straipsnyje analizuojama Radviliškio rajono Baisogalos, Radviliškio ir Šeduvos valsčių agronimų daryba, kuri papildoma semantine analize. Agronimai rinkti praejusio šimtmečio pirmojoje pusėje ir dabar saugomi Lietuvių kalbos instituto Vardyno skyriuje. Tiriamąją medžiagą sudaro 1185 (936 neskaitant pasikartojančių) agronimai, išrašyti iš Žemès vardų anketų. Agronimų darybos analizè pateikiama remiantis A. Vanago toponimų struktūrine-gramatine schema: išskirti pirminiai ir antriniai agronimai toliau skirstomi ị smulkesnes darybines grupes.

Atlikta agronimų darybinè analizè rodo, kad daugiau užrašyta antrinių agronimų, turinčių derivacinių požymių (57,7 \%). Apie pusę (54,6 \%) antrinių agronimų grupès sudaro vediniai. Smulkesnè vardų klasifikacija atskleidè, kad daugumą jų sudaro priesagų vediniai (78,6 \%), kurių darybai pavartotos 29 priesagos. Mažesnes vedinių grupes sudaro galūnių $(9,5 \%)$ ir priešdèlių $(11,9 \%)$ vediniai. Galūnių vedinių darybai pavartotos 7 galūnès. Priešdèlių vedinių darybai pavartoti tik 3 priešdèliai: pa-, pri-, už-. Mažesnė antrinių agronimų grupe yra dūriniai (29,1\%). Mažiausiai rasta sudètinių vardų (16,3\%). Šioje grupejje populiariausi kilmininkiniai agronimai (85,2\%), kurių pirmasis komponentas - bendrinis daiktavardis $(58,7 \%)$.

Pirminių agronimų rasta 364 (38,9\%). Analizè rodo, kad absoliučią jų daugumą sudaro daiktavardiniai agronimai $(95,9 \%)$.

Ateityje numatoma visų Radviliškio rajono agronimų darybos analizė papildys šiame straipsnyje pateiktus duomenis, suteiks galimybę juos lyginti su kitų rajonų agronimais, atskleisti būdingus agronimų darybos bruožus.
\end{abstract}

Raktažodžiai: agronimas, darybinè analizé, vietovardis

\section{IVADAS}

Vardynas - labai savita leksikos dalis, kuri yra daugelio kalbininkų tyrimų objektas. Ypač daug tyrejų dėmesio sulaukia vietovardžiai, t. y. toponimai. Jie tarsi dokumentai, kuriuose kalbininkai įžvelgia kalbos kaitą ir praeities istorijas. Šis vardyno sluoksnis pateikia svarbių duomenų ne tik lingvistikai, bet ir kitoms mokslo šakoms, be to, jis nuolat kinta. Dèl praktinès žmogaus veiklos atsiranda naujų vietovardžių, tačiau daug dažniau - vietovardžiai išnyksta. Kaip tik dèl to labai svarbu vietų vardus rinkti, užrašyti ir tirti. 
Lietuvių toponimija yra gana išsamiai tiriama. Bene geriausiai ištirta vietovardžių poklasė - hidronimai. Juos darybiškai, etimologiškai ir semantiškai išanalizavo Aleksandras Vanagas $[22 ; 23 ; 24]$. Jis taip pat tyrė Lietuvos gyvenamųjų vietų vardų kilmę [25]. Darybos požiūriu oikonimiją išsamiausiai ištyrè Marija Razmukaitė daktaro disertacijoje [18]. Laimutis Bilkis paskelbė monografiją apie priesaginių helonimų darybą [1], Dalia Kačinaitė yra parašiusi disertaciją apie priesaginių oronimų darybą [8]. Atskirų regionų vietovardžiai ištirti I. Mickienès [16], R. Endzelytės [3], N. Bartkutès [2] disertacijose.

Lietuvių toponimikos darbų yra daug ir įvairių, tačiau kai kurios toponimų poklasės dar mažai tirtos, pavyzdžiui, nèra daug agronimams skirtų darbų. Agronimų daryba analizuojama R. Endzelytès [4, 80-89], I. Mickienès [17, 27-30] ir D. Sviderskienès [19, 97-127; 20, 81-98] straipsniuose.

Šio straipsnio tyrimo objektas: Radviliškio rajono Baisogalos, Radviliškio ir Šeduvos valsčių agronimai. Radviliškio rajonas - administracinis teritorinis vienetas Šiaurès Lietuvoje (1 pav.). Ši rajoną sudaro septyni buvę valsčiai: Baisogalos, Grinkiškio, Pašušvio, Radviliškio, Sidabravo, Šeduvos ir Šiaulènų. Darybinei agronimų analizei buvo pasirinkti trys dabartineje Radviliškio rajono teritorijoje buvę valsčiai: Baisogalos, Radviliškio, Šeduvos (2 pav.). Pasirinkimą tirti Baisogalos, Radviliškio ir Šeduvos valsčius lėmé tai, kad šie valsčiai buvo didžiausi, o jų centrai ir šiandien yra didžiausios gyvenvietès rajone.

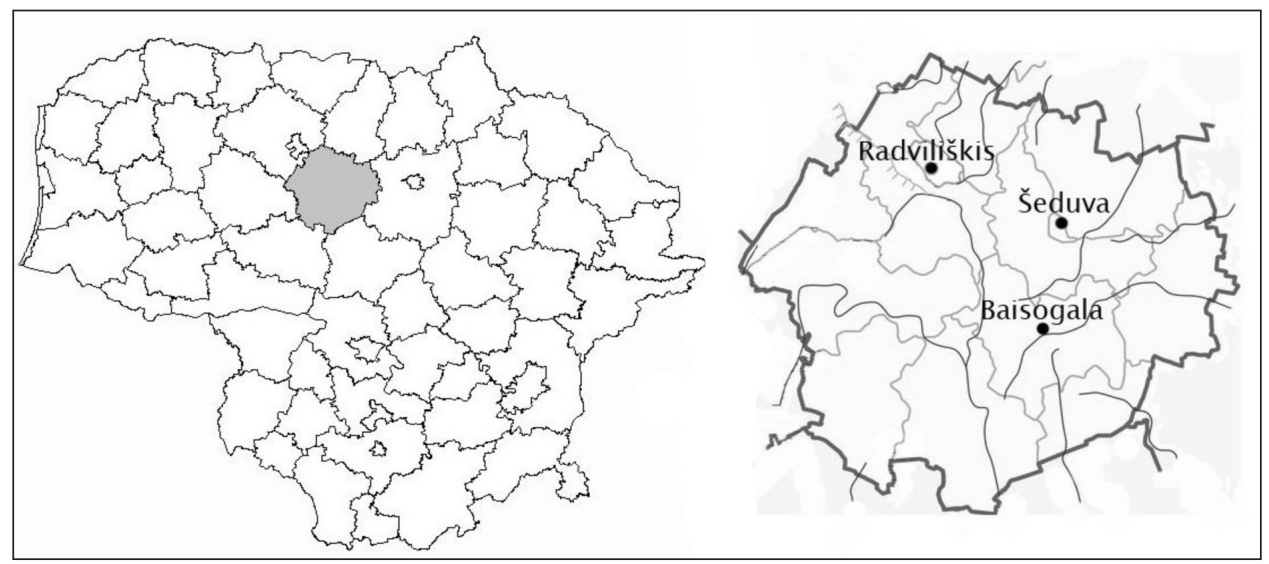

1 pav. Radviliškio rajonas (kairèje), Radviliškio, Šeduvos mst. ir Baisogalos mstl. (dešinėje)

Tyrimo tikslas - apžvelgti Baisogalos, Radviliškio ir Šeduvos agronimų darybos tendencijas:

Straipsnio medžiaga: 1185 (936 neskaitant pasikartojančių) agronimai, išrašyti iš Lietuvių kalbos instituto Vardyno skyriuje saugomų Žemės vardų anketų.

Tyrimo metodai - struktūrinè ir kiekybinè duomenų analizė.

Trijų didžiausių Radviliškio rajono valsčių - Baisogalos, Radviliškio ir Šeduvos - agronimų analizė papildys dar mažai analizuotos toponimų poklasės tyrimus. 


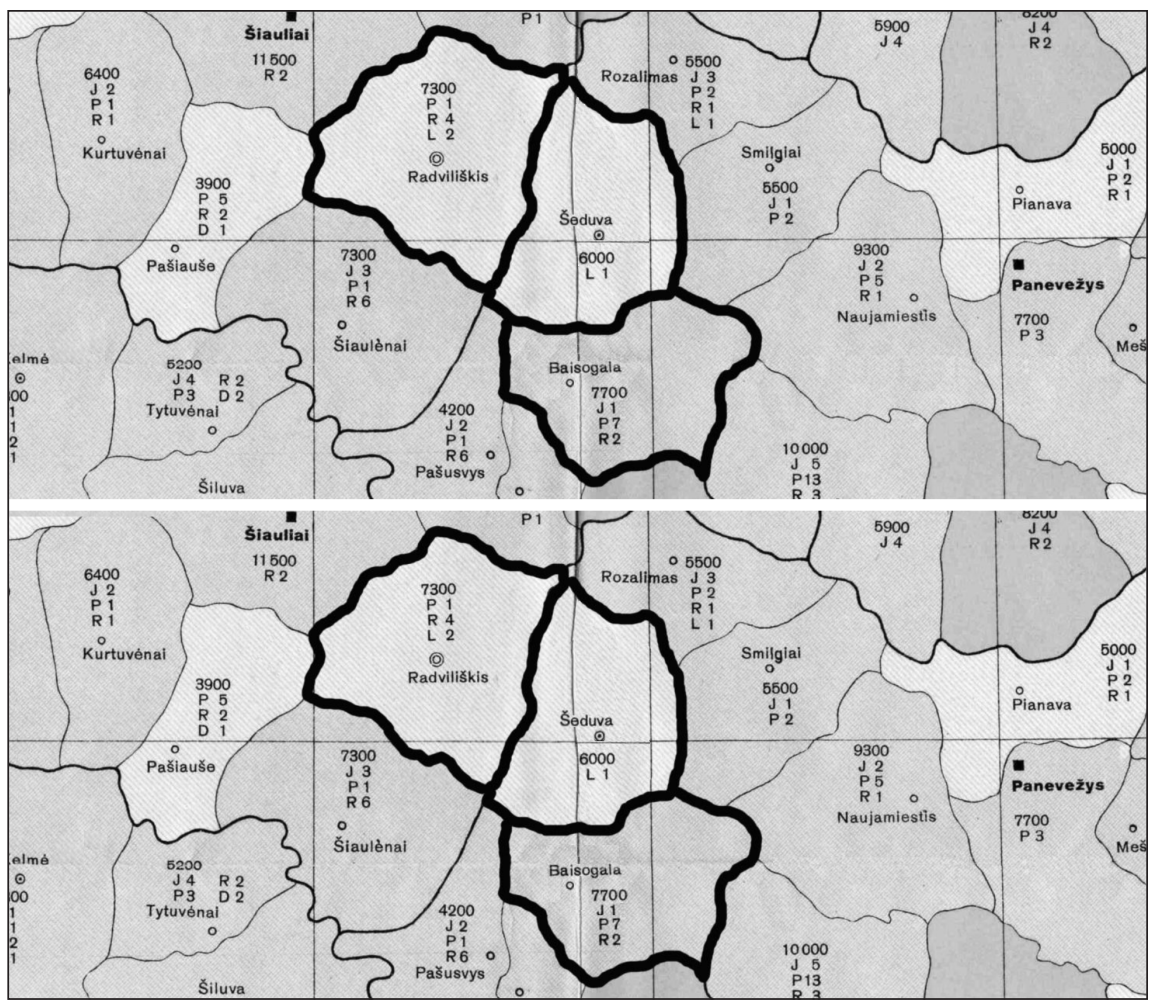

2 pav. Radviliškio, Šeduvos ir Baisogalos valsčiai (1)

\section{TIRIAMOSIOS MEDŽIAGOS APRAŠAS}

XX a. 4-ajame dešimtmetyje Lietuvos Respublikos Švietimo ministerijos Valstybės archeologijos komisija susirūpino vietovardžių rinkimu ir inicijavo visos Lietuvos žemès vardyno rinkimą. Buvo sudarytos specialios Žemès vardų anketos, kurias dažniausia pildè pradinių klasių mokytojai ir girininkai. Toks duomenų rinkimas argumentuojamas $1934 \mathrm{~m}$. K. Alminauskio sudarytoje vietovardžių rinkèjų instrukcijoje: „Kadangi tiksliai ir pilnai žemès vardyną tegalima surinkti vietoje iš tenai gyvenančių žmonių, tat Švietimo ministerijos nuomone, tą labai sunkų ir atsakingą darbą beveik visame Lietuvos krašte geriausiai galès atlikti pradžios mokyklų mokytojai. Valstybinių miškų žemėvardžius surašyti tinkamiausiai galès girininkai“ [11]. Taip per kelerius metus buvo surašyti visų Lietuvos miestų, miestelių, kaimų, vienkiemių, bažnytkaimių ir girininkijų teritorijose buvę vietų vardai. Kiekvienai gyvenamajai vietai buvo skirta atskira anketa. Iš viso buvo užrašyta apie 150000 vietovardžių. Dabar užpildytos anketos yra saugomos Lietuvių kalbos instituto Vardyno fonduose ir yra patogus, autentiškas ịvairių mokslinių tyrimų ar duomenų bazių šaltinis.

Medžiaga straipsniui buvo rinkta ir iš Žemès vardų anketų. Lietuvių kalbos instituto Vardyno fonduose yra saugomos 103 anketos, skirtos Baisogalos valsčiaus vietų vardams.

(1) 1-as žemèlapis - 1929 m. (parengtas lenkų), 2-as žemèlapis - 1939 m. (parengtas vokiečių). Abu žemèlapiai rasti internetiniame puslapyje http://www.lithuanianmaps.com/ [žiūrèta 2014 04 09]. 
Radviliškio valsčiaus fondą sudaro 75 anketos, Šeduvos - 62. Daugiausiai anketų buvo skirta kaimų pavadinimams, mažiau - vienkiemių, dvarų ir tik po kelis - fermų ir miestų vardams. Tikètina, kad anketose, fiksuojant medžiagą iš gyvosios kalbos, galèjo įsivelti klaidų; net ir užrašant oficialų pavadinimą vietovès, iš kurios buvo renkami vardai. Dèl to visi vietovardžiai buvo tikrinti (2) [28]. Taip pat buvo rasta netikslumų nurodant vietovès rūši. Kai kurie anketose pažymèti vienkiemiai oficialiuose šaltiniuose nurodomi kaip kaimai - tokiu atveju skliausteliuose pažymima santrumpa $k$ :

Baisogalos, Radviliškio, Šeduvos valsčiuose vietų vardus užrašè 41 rinkẻjas. Visi analizuotų anketų rinkèjai buvo pradinių klasių mokytojai, dirbę ir gyvenę tose vietovėse. Jie apklausẻ 167 gyventojus. Prie šio skaičiaus reikètų pridèti dar mažiausiai 60 gyventojų, nes būtent 60 -yje anketų žinių teikejjai nebuvo nurodyti. Šios anketos yra puiki medžiaga vietovardžių analizei.

\section{BAISOGALOS, RADVILIŠKIO IR ŠEDUVOS VALSČIU AGRONIMU DARYBA}

Agronimai - įvairių žemès plotų: laukų, arimų, dirvų, pievų ir pan. - vardai. Terminas agronimas nèra dažnai vartojamas, nes ši toponimų klasė mažai tyrinèta. Tiriant Telšių rajono toponimus, buvo pastebėta, kad nèra termino, kuriuo būtų galima įvardyti pievų, laukų, ganyklų ir pan. vardus, o kitos toponimų klasės jau turèjo savus terminus. Atkreipus démesi i tai, kad lietuvių toponimikoje jau prigiję tarptautiniai atskirų vietovardžių klasių pavadinimai, buvo pasirinktas rusų lingvistineje literatūroje vartojamas terminas agronimas: jo pirmasis sandas nurodo įvardijamą objektą (gr. Agros - „laukas, dirva“), o antrasis sandas - žodis onimas (gr: onyma - „vardas“) [plg. 17, 27].

Straipsnyje aptariamų agronimų reikšmès aiškinamos pasitelkus ịvairius šaltinius: Lietuvių pavardžių žodyną, K. Kuzavinio, B. Savukyno Lietuviu vardų kilmès žodyną, Vietovardžiu žodyną, Lietuviu kalbos žodyna (LKŽ), Ch. Lemcheno, J. Masaičio Rusųlietuvių kalbų žodyną, V. Vaitkevičiūtès Didiji lenkų-lietuvių kalbų žodyna ir kt.

Žemès vardų anketose buvo rasti 407 sukirčiuoti agronimai. Tai sudaro 43,5\% visų anketose esančių agronimų. Jei agronimas nebuvo sukirčiuotas arba jo kirčiavimas neaiškus ar nepatikimas, straipsnyje jis taip pat paliktas nekirčiuotas:

\section{PIRMINIAI AGRONIMAI}

Iš viso buvo rasti 364 pirminiai agronimai. Tai buvo daiktavardiniai ir būdvardiniai agronimai.

\subsection{Daiktavardiniai}

Iš visų pirminių agronimų buvo rasti 349 daiktavardiniai agronimai. Juos dar galima skirstyti pagal kilmę.

Agronimai iš fiziografiniu terminu

Rasti 82 šios rūšies agronimai. Pvz.: Aikštė pv. (Vlž. k.): aikštẽ „miške lygi, be medžių, mieste be namų vieta“; Apydèmé a. ž. (Vl. dv.): plg. apidème „sodžiaus bendras žemès sklypas tarp dviejų sodybų“; Balà 2 pv., 1 (3) l., 1 a. ž. (Vntn. k., Klč. k., Kmrš. k., Pšl. k.): balà „klampi vieta, dažniausiai su stovinčiu joje vandeniu“; Kálnas 3 drv. (Ldš. k., Vlž. k., Krk. k.): kálnas „aukštas žemès pakilimas“; Klynas gn. (Ldš. k.): klỹnas „trikampio pavidalo žemès plotas,

(2) Vietovardžiai tikrinti pagal $1923 \mathrm{~m}$. pirmojo Lietuvos gyventojų surašymo duomenis, kurie pateikti „Versmès“ leidyklos internetiniame puslapyje [žiūrèta 201404 10]. Prieiga per internetą: http://www. versme.lt/seduva_kaimai.htm; http://www.versme.lt/bais_kaimai.htm:

(3) Skaičius žymi anketose rastų objektų skaičių. 
kyšulys“; Klum̃upupis pv. (Šd. mst.): plg. klã̃pupis „klampi, pelkèta upe“; Küdra pv., b. (Bd. vnk.): kúdra „nedidelis tvenkinys“; Lañka 2 pv. (Kmrš. k., Ppl. k.): lankà „didelè lygi pieva, dažniausiai prie upès“; Laukas 1 a. ž., 1 pv. (Dvk. k., Už. k.): laũkas „žemès plotas, dirva“; Líekna 3 pv. (Gnd. k., Avž. k., Kmrš. vnk.): líekna „žema drègna pieva be krūmų“; Majakas pv. (Krč. k.): mãjakas „sklypas“; Pleska buv. rž. (Slk. k.): pleskà „padalyto žemės rèžio dalis“; Pridočkas l. (Klb. k.): pridóčkas žr. pridõtkas „pridètinis žemès sklypas“; Prūdas pv. (Už. k.):

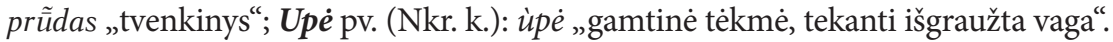

Šią agronimų grupę ir A. Vanago sukurtą klasifikaciją papildo daugiskaitiniai (pluralia tantum) toponimai. Pluralia tantum agronimai yra: Barãbanai gn. (Šil. k.): dgs. iš barabãnas žr. barabanỹnè „menkai sužèlusi dirva, ganykla“; Brastos pv., d. ž. (Šil. k.): dgs. iš brastà „negili upès vieta, per kurią galima perbristi“; Duburiai l. (Skn. k.): dgs. iš duburỹs „ịdubimas žemèje, duobè, dauba“; Duõbès pv. (Pp. k.): dgs. iš duobẽ „iškasta ar šiaip įdubusi vieta žemèje“; Kluonai 2 pv. (Nkr. k., Pln. k.): dgs. iš klúonas „didesnis žemès sklypas“; Šaltìniai 1 pv., 1 a. ž., pv. (Andr. k., Bsg. frm.): dgs. iš šaltìnis „iš žemès tekanti vandens versme““; Trainiai pv. (Skm. k.): dgs. iš trainỹs žr. treinỹs „prasta pieva, ganykla“.

Agronimai iš daiktavardžių - įvairių vietų pavadinimų

Rasti 132 tokie agronimai, pvz.: Akmenỹne 2 pv. 1 a. ž., 1 gn., 2 drv. (Ar. k., Kaul. k., Kat. k., Miež. k., Krk. k., Pvrt. k.): akmenỹne „dirva, žemė, kur daug akmenų“; Asiūklyne drv. (Krč. k.): asiūklỹne „vieta, kur asiūkliai auga“; Apušynas a. ž. (Dkn. dv.): plg. epušýnas „epušių miškas“; Azžuolýte pv. (Prš. k.): ąžuolýte „ąžuolynèlis“; Blindyne drv. (Vlž. k.): blindỹne „vieta, kur auga daug blindžių“; Klampyne pv. (Už. k.): klampỹne „klampi vieta“; Kupstỹne 1 pv., 3 gn. (Grž. k., Nkr. k., Pbrž. k., Vlg. k.): kupstỹnè „kupstuota vieta, pieva“; Pempỹne pv. (Bsg. frm.): pempỹne் „vieta, kur pempès peri“; Samanyné pv., drv. (Sd. k.): samanỹne „samanų priaugusi vieta“; Skerdimas pv. (Sd. k.): skerdimas „iškirsta miške vieta, skynimas“; Šermukšnỹnè a. ž. (Pp. k.): šermukšnỹnė „vieta, kur auga daug šermukšnių“; Viganas pv. (Miež. k.): vìganas „aptvertas kelias gyvuliams varyti“; Žỹdkapis 1 a. ž., 1 d. ž. (Prš. dv., Bbr. k.): ž̃̃ydkapis žr. ž̃̃ykapiai „žydų kapinès“; Žvyrýnas a. ž. (Kmrš. k.): žvyrýnas „vieta, kur daug žvyro“.

Pluralia tantum agronimai, pvz.: Degimaĩ 5 pv. (Kat. k., Skn. k., Žr. k., Gnk. k., Kbl. k.): dgs. iš degìmas „išdegusi vieta“; Kupstynès gn. (Šnr k.): dgs. iš kupstỹne „kupstuota vieta, pieva“; Laužỹnès 1. (Ltk. k.): dgs. iš laužỹnè žr. laužýnas „vieta miške, kur daug prilūžusių šakų, žabų“; Smiltýnai a. ž. (Jdp. k.): dgs. iš smiltýnas „vieta, kur daug smilčių, smèlynas“; Žỹdkapiai 1 a. ž., 1 d. ž., pv. (Šlk. k., Vrš. k.): žỹdkapiai „žydų kapinès“.

Agronimai iš kitu toponimu

Rasti 76 tokie agronimai. Pvz.: Aĩksnupis sln. (Alk. k.): Aĩksnupis up. Rdvl. r.; Bérž̇e pv. (Gmb. k., Knv. k., Ltk. k.): Beržé up. Rdvl. r.; Bebrùjai pv. (Bbr. k.): Bebrùjai k. Rdvl. r.; Brùzdelè pv., a. ž. (Až. k.): Brùzdelè up. Rdvl. r.; Guĩbinas 2 gn., 1 1. (Lnšk. k., Skr. k.): Guĺbinas up. Rdvl. r.; Kutena pv. (Kll. k.): Kutenà up. Rdvl. r.; Pãkapė pv. (Šnr. k.): Pãkapė up. Rdvl. r.; Pátaušis 1. (Skr. k.): Pátaušis vnk. Rdvl. r.; Postupis pv. (V̌̌. k.): Postupis up. Rdvl. r.; Ringužis pv. (Blt. k.): Riñgužis up. Rdvl. r.; Vanaginė d. ž. (V̌̌. k.): Vanagìnè up. Rdvl. r.; Zabranas a. ž. (Kll. k.): Zabrãnas k. Jrb. r.

Pluralia tantum agronimai: Dubùliai sln. (Šd. mst.): dgs. iš Dubùlis up. Rdvl. r.; Zabranai drv. (Ar. k.): dgs. iš Zabrãnas k. Jrb. r.

Agronimai iš asmenvardžiu

Iš viso rasta 11 tokios rūšies agronimų. Tai pievos, dirvos ir kt. vietos, pavadintos buvusių ar esamų šeimininkų pavardėmis. Pvz.: Kirkyla pv. (Alk. k.): Kirkylà avd.; Letukas pv. (Pšk. k.): Letùkas avd.; Nazarauskas a. ž. (Žn. k.): Nazaráuskas avd.; Prakopas pv. (Pvrt. k.): 
Prãkopas avd.; Júodvalkis 2 pv. (Mnk. k., Pp. k.): Júodvalkis avd.; Pūniškis a. ž. (Jnk. k.): plg. Puniškis avd.; Vališkis pv. (Miež. k.): Valškis avd.

Pluralia tantum agronimai: Kalvaičiai pv. (Gk. k.): dgs. iš Kalváitis avd.; Kirveliai pv. (Kaul. k.): Kirvẽlis avd.; Plendžiai pv. (Prš. k.): dgs. iš Plendỹs avd.; Valentaĩ l. (Grb. k.): dgs. iš Vãlentas avd.

Agronimai iš augalu pavadinimu

Rasti 3 agronimai, kurie apibūdina žemès plotus pagal augaliją. Pvz.: Baltalksnis pv. (Ššn. k.): baltalksnis „tokios alksnių rūšies medis“; Peliùška drž. (Grž. k.): peliuškà „ankštinis augalas, vartojamas pašarui, dirvinis žirnis“.

Pluralia tantum agronimas: Kamarkos (Krkl. dv.): dgs. iš kamarka „tokia žolë“.

Agronimai iš gyvūnu (ir vabzdžiǔ) pavadinimu

Rasti 3 agronimai, kurie apibūdina žemès plotus pagal toje vietoje gyvenančius ar kitaip su ja susijusius gyvūnus. Pvz.: Avinễlis a. ž. (Prš. dv.): avinếlis „èriukas, avinukas“; Marele šl. pv. (Brn. k.): marẽlè „vabalų būrio vabzdys, boružë; Študas gn. (Pbrž. k.): štùdas „prastas, senas arklys, kuinas“.

Agronimai iš įvairių konkrečios ar abstrakčios reikšmès daiktavardžių

Rasti 42 tokie agronimai. Pvz.: Barãkas pv. (Lp. k.): barãkas „laikinas gyvenamas pastatas“; Dalgis pv., b. (Pr. k.): dalgis „irankis žolei ar javams pjauti“; Drumbla pv. (Ar. k): drùmbla „apdribèlis“; Kélnés pv. (Kmr. k.): kélnès „ant juosmens ir kojų dèvimas drabužis“; Klètele pv., tr. (Už. k.): kletễè „vidurinė klètis namų apyvokos daiktams, daržovèms ir alui laikyti“; Kubilas pv. (Vlž. k.): kùbilas „statinè plačiu dugnu“; Stokas a. ž., pv. (Pln. k.): stokas „tvoros statinis“; Tartokas a. ž., krm. (Lb. k.): tartõkas „lenpjūvë“.

Pluralia tantum agronimai. Pvz.: Balaganai l. (Skn. k.): balagãnas „laikina lentų ar audeklo pastogè, pašiūre““; Dum̃alès 1 drv., 1 pv. (Gnd. k., Pr. k.): dgs. iš dum̃blè „dumblo žemë“; Láužai 1 b., gn., 1 a. ž. (Bln. k., Kmrš. k.): dgs. iš láužas „suversta kokių nors daiktų krūva“.

\section{Būdvardiniai agronimai}

Rasta 15 būdvardinių agronimų, kurie apibūdina žemès plotus pagal spalvą, dydị ir pan. Pvz.: Baltine pv., drv. (Pkln. k.): baltìne „kuri baltos spalvos“; Gražióji pv. (Taut. k.): ịv. f. iš graži „daili, teikianti pasigèrẻjimo“; Kepurèta gn. (Miež. k.): kepuréta „kuri su kepure“; Pirktìne drv. (Klč. k.): pirktìne „ne nuo seno turèta, o įsigyta, pirkta“; Plačiùkè a. ž. (Vlk. k.): plačiùke „plati“; Sidabrine pv. (Gnk. k.): sidabrìne „žvilgejeimu ir spalva panašus i sidabrą“; Šilkinè pv. (Pr. k.): šilkìne „minkštas, švelnus ar žvilgantis kaip šilkas“.

Pluralia tantum agronimai: Aukštieji a. ž. (Vlk. dv.): dgs. įv. f. iš áukštas „turintis didelị aukštti“; Plačiokés pv. kln. (Vn. k.): plg. dgs. iš. Plačiùke „plati“; Plačiùkès 2 a. ž. (Grn. k. Kmrš. k.): dgs. iš plačiuke; Šlãpios pv. (Šil. k.): dgs. iš šlapià „skysčio prisigèrus, sumirkus“.

\section{ANTRINIAI AGRONIMAI}

Iš viso rasta 540 antrinių agronimų. Darybiškai juos galima skirstyti ị vedinius, sudurtinius ir sudetinius.

\subsection{Vediniai}

Rasti 295 vediniai. Juos smulkiau galima skirstyti ị priesagų, galūnių ir priešdèlių vedinius.

\subsubsection{Priesagu vediniai}

Iš viso rasti 232 priesagų vediniai. Juos dar galima skirstyti pagal priesagas, kurių buvo rasta 29. 
Priesaga -aič-

Rastas vienas priesagos vedinys: Navìd-aičiai 1 drv., 1 l. (Pvrt. k., Šd. mst.): Navidas avd.

Priesaga -ait-

Rasti 3 priesagos vediniai: Bal-áitès 3 pv., 1 šl. gn. (Jnk. k., Šnr. k., Jdp. k., Ššn. k.): balà „klampi vieta, dažniausiai su stovinčiu joje vandeniu“; Bal-áitis pv. (Nkr. k.): balà; Il-aitès drv. (Jkn. k.): Ilà avd.

Priesaga -auk-.

Rastas vienas priesagos vedinys: Plent-auka pv. (Krč. k.): pléntas „smulkiais akmenimis grịstas ar tam tikra mase lietas kelias“.

Priesaga -ed-

Rastas vienas priesagos vedinys: $\mathbf{R o p}$-edos gn. (Jdp. k.): rópe „pašarinè ar valgomoji daržové“.

Priesaga $-\dot{e} d-$

Rasti 2 priesagos vediniai: $\boldsymbol{R o p}$-édai a. ž. (Vl. k.): rópé; $\boldsymbol{R o p}$-èdžiai a. ž. (Vbl. k.): rópée.

Priesaga -el-

Rasti 59 priesagos vediniai. Pvz.: Bal-ẽlè sln. (Žb. k.): balà „klampi vieta, dažniausiai su stovinčiu joje vandeniu“; Geld-ẽle pv. (Kmr. k.): gélda „lomelè, duobė dirvoje“; Gryb-elis pv. (Kat. k.): grỹbas „glebus, minkštas sporinis augalas, kremblys“; Kap-ẽliai 1 a. ž., kln., 1 žv., 1 d. ž., 2 a. ž. (Agm. k., Pšk. k., Drg. k., Lb. k., Pž. k.): kapã̃ „vieta, kur laidojami žmonès“; Kirv-ẽlis d. ž. (Gv. k.).: kir̃vis „irankis kam kirsti, tašyti“; Liūn-eliai drv. (Aukšt. k.): liúnas „liumpsinti pelkè dèl po durpèmis slūgsančio vandens“; Pagir-elis a. ž. (Vl. k.): pagirỹs „girios pakraštys, laukas prie girios“; Pamérk-eliai a. ž. (Šnk .k.): pamer̃kti „sudèti, ịkišti ị vandenį“; Vinkšn-ẽle d. ž.. (Srt. k.): vìnkšna „guobinių šeimos medis“:

Priesaga -èl-

Rasta 17 priesagos vedinių. Pvz.: Beržyn-èlis 1 šl. pv., 1 pv. (Ldš. k., Krč. k.): beržýnas „beržų miškas“; Bravar-èlis l. (Bčn. k.): brãvaras žr. brãvoras „spirito ar alaus darykla“; Dirvon-èlis pv. (Ar. k.): dirvónas „apleista, nedirbama, sužèlusi dirva“; Eglyn-èlis 1 gn., 1 gn., krm. (Ldš. k., Taut. k.): eglýnas „eglių miškas“; Ežer-èlis 2 pv., 1 a. ž. (Vl. k., Ldš. k., Vš. dv.): ẽžeras; Kupstyn-èlis gn. (Šnr. k.): kupstýnas „vieta, kur daug kupstų, kemsynas“; Užvar-èlis pv. (Bbr. k.): ùžvaras „aptverta vieta, aptvaras“.

Priesaga -en-

Rasti 6 priesagos vediniai. Pvz.: Akm-ẽne 2 a. ž. (Až. k., Prš. dv., Pčgl. dv.): akmuõ „kieta uoliena arba jos atskiras gabalas“; Mẽd-enos 2 a. ž. (Pbrž. k., Drg. k.): mẽdis „daugiametis augalas su kietu kamienu ir šakomis“; Pùnd-enis drv. (Rk. k.): pùndas „ryšulys; svorio matas“; Šlap-enè pv. (Ant. vnk.): šlãpe „šlapia pieva, dirva“. Vienas iš vedinių turi dvi priesagas - -en- ir -ij-: Kump-en-ija a. ž. (Skm. k.): Kùmpa avd.

Priesaga -er-

Rastas vienas priesagos vedinys: Dvar-eriai a. ž. (Pr. k.): dvãras „dvarininko ūkis, sodyba“.

Priesaga $-e \check{s}-$

Rastas vienas priesagos vedinys: Súod-ešis d. ž. (Gmb. k.): súodis „anglis, virtusi skrajojančia suodim“.

Priesaga $-y \check{c}$ -

Rastas vienas priesagos vedinys: Sulin-yčios pv. (Krk. k.): sulinis „turintis sulos“.

Priesaga -ien- 


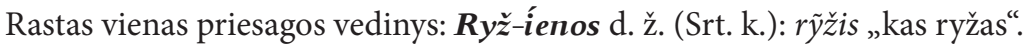

Priesaga -ij-

Rastas vienas priesagos vedinys: Maskol-ija pv., a. ž. (Vrš. k.): maskõlius „caro kariuomenès kareivis".

Priesagos -il-, -in-

Rastas vienas dviejų priesagų vedinys: Dag-il-iné a. ž. (Vbl. k.): dagỹs „dygliuota graižažiedžių šeimos piktžolë“, nors šis agronimas galètų būti ir vienos priesagos vedinys iš asmenvardžio Dagilis.

Priesaga -im-

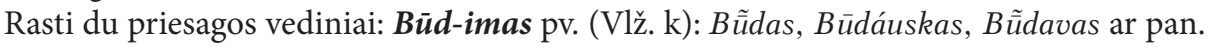
avd.; Desent-imos drv. (Skn. k.): dešimtinè „žemès ploto vienetas“ (plg. rus. десятина).

Priesaga -in-

Rasti 34 priesagos vediniai. Pvz.: Baránk-inė 1 a. ž., 1 l. (Mrgv. dv.): baránka „riestainis“; Jasait-ìnè l. (Mtk. dv.): Jasáitis adv.; Kapač-inẽ̃lès a. ž. (Už. dv.); Kapačiúnas, Kapačiáuskas ar pan. avd.; Paužvar-ìne buv. rž. (Šnk. k.): paužvarỹs „vieta, laukas palei kelią, užvarą, kuriuo galvijai varomi ị ganyklą“; Penkiolik-ìne buv. rž. (Šnk. k.): penkiólika „skaičius 15“; Tilvìk-ine a. ž. (Mrgv. dv.): tiklvikas „balsingas karvelio didumo pelkių ir vandenų pakrančių paukštis“.

Priesaga $-y n-$

Rasti 26 priesagos vediniai. Pvz.: Brast-ỹnè a. ž. (Ppl.ž. k.): brastà „negili upès vieta, per kurią galima perbristi“; Daujot-yne drv. (Lnk. k.): Daũjotas avd.; Dauǩšñ $\boldsymbol{n} \dot{\boldsymbol{e}}$ a. ž. (Bsg. frm.): Daukšà avd.; Garad-ynè gn. (Miež. k.): garãdas „tvoros basliukas“; Lukšt-ynès a. ž. (Miež. k.): lùkštas „vèdryninių šeimos augalas, pelkiné puriena“; Mešk-yné a. ž. (Vl. k.): meškà „lokys“; Savì̀ck-ynè pv. (Knv. k.): Savìckas avd.; Šilk-ynẻ pv. (Sd. k.): šillkè „pievų augalas; šilkažolë; Šidlausk-ỹnè drv. (Mž. k.): Šidláuskas avd.

Priesaga -išk-

Rasti 47 priesagos vediniai. Pvz.: Abrom-ì̀skis a. ž. (Pbrž. k.): Abrõmas avd.; Bagdõniškis pv. (Slb. k.): Bagdõnai k. Rdvl. r.; Gérv-iškis a. ž. (Srt. k.): gérvé „didelis pelkių paukštis“; Jókub-iškis d. 1. (Vl. vnk.): plg. Jokũ bas avd.; Katilior-iškis skl. (Šd. mst.): katiliorius žr. katilius „katilų dirbëjas“; Kaziùl-iškis a. ž. (Pp. k.): Kaziùlis avd.; Kerbed-ì̀skis drv. (Ldš. k.): Kerbedis avd.; Kùrk-iškis a. ž. (Šlk. k.) kùrkis „kalakutas“; Medel-iškis (Krk. k.): medẽlis „mažas medis“; Méld-iškès drv., b. (Jkn. k.): méldas „viksvinių šeimos augalas“; Žióg-iškis a. ž. (Bbr. k.) žiógas „šoklus tiesiasparnių būrio vabzdys“Žvì̀rbl-iškis pv. (Šd. mst.): žvìrblis „kikilių šeimos sodybų, miestų nedidelis paukštis“.

Priesaga $-y t-$

Rasti du vediniai, turintys šią priesagą. Vienas iš vedinių turi tik priesagą -yt-: Spalgenýte 1 pv., 1 a. ž., 1 pv., b. (Ldš. k., Pp. k., Už. k.): spalgena „spanguole““. Antrasis turi dvi priesagas: Lank-yt-inis pv. (Pkln. k.): lankà „didelè lygi pieva, dažniausiai prie upès“;

Priesaga $-k$ -

Rastas vienas priesagos vedinys: Gor-ka a. ž. (Srt. dv.): plg. rus. zopa (liet. kalnas).

Priesagos -on-, -išk-

Rastas vienas dviejų priesagų vedinys: Ulm-on-ì̀skis drv. (Aukšt. k.): Ùlmis avd.

Priesaga -(i)uk-

Rasta 16 priesagos vedinių. Pvz.: Ąžuol-iukas gn. (Grž. dv.): ąžuolas „labai kietas medis, auginantis giles“; Bal-iuke pv. (Kat. k.): balà „klampi vieta, dažniausiai su stovinčiu joje vandeniu“; Dvarlauk-iukai drv. (Ar. k.): dvárlaukis „seniau buvęs dvaro laukas“; Gaidž-iùkai 
1 a. ž., 1 pv. (Jdp. k., Pž. k.) gaidỹs „naminis paukštis“; Gaidžvalak-iukai buv. rž. (Nj. k.): gaĩdžvalakis „nedidelis žemès rèželis“; Plesk-iùkai a. ž. (Pž. k.): plẽskas žr. pleskà „padalyto žemès rèžio dalis“; Train-iùkai buv. rž. (Nj. k.): trainys žr. treinys „prasta pieva, ganykla“; Žvail-iukas pv. (Bd. vnk.): žvailùs „Žvairas“.

Priesaga -(i) ük-

Rastas vienas priesagos vedinys: Ganykl-iūkai pv. (Vbl. dv.): ganyklà „ganomoji vieta“. Priesagos -ul-, -in-

Rastas vienas dviejų priesagų vedinys: Kap-ul-ine a. ž. (Dvk. k.): kãpas „vieta, kur numirèlis palaidotas“.

Priesaga $-u t$ -

Rasti 5 priesagos vediniai. Pvz.: Berž-utis pv. (Ilg. k.) béržas „lapuotas medis balta tošimi“; $\boldsymbol{E} \boldsymbol{g l}$-utè pv. (Grž. dv.): ẽglè „visada žaliuojantis spygliuotis medis“; Pelk-ùtė 1 pv., pl., 1pv. (Brnč. k., Agm. k.): pélkẻ „nuolat šlapia žemè, dažnai su durpių klodu“. Vienas šiai grupei priskirtų vedinių turi dvi priesagas: Kap-ut-ýnai a. ž. (Užp. k.): kãpas „vieta, kur numirèlis palaidotas“.

\subsubsection{Galūnių vediniai}

Rasti 28 galūnių vediniai. Juos smulkiau galima skirstyti pagal galūnę.

Galūnè - $a$

Rasti du galūnès vediniai iš hidronimo. Pvz.: Gyl-a pv. (Pbrž. k.): Gylè up. Rdvl. r.; Šiekštum-a pv. (Vlž. k.): Šiekštumas up. Rdv. r.

Galūnè -as

Rastas vienas galūnès vedinys iš hidronimo: Velèkl-as pv. (Klč. k.): Velèkla up. Rdvl. r.

Galūnè -(i)ai

Rasti 7 galūnès vediniai. Pvz.: Núolaid-ai ž. (Vd. k.): núolaidis „nuožulnumas, nuolydis“; Pridõčk-iai 1 pv., 1 l., 1 skl. (Pž. k., Šd. mst., Už. k.): pridóčkas žr. pridõtkas „pridètinis žemès sklypas“; Pur̃v-iai pv. (Pb. k.): plg. pur̃vas „vieta, kur patižusi žemè, purvynas“, pur̃ve „Šlapia vieta, paversmis“.

Galūnè - $\dot{e}$

Rasti 5 galūnès vediniai. Pvz.: Pabrukìn-è buv. rž. (Šnk. k.): pabrukinéti „pavarinèti, pa-

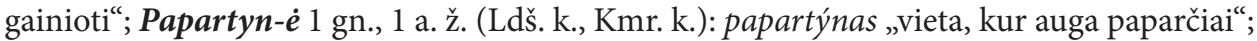

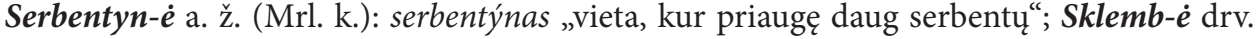

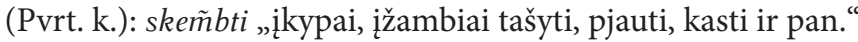

Galūnè -is

Rasti 8 galūnès vediniai. Pvz.: Gỹvačbal-is pv. (Knv. k.): gyvãčbale „pelkè, kurioje daug gyvačių“; Kiugel-is drv. (Vnt. k.): kiugêle „nedidelis kupetèlis, kūgelis“; Malštov-is pv. (Dk. k.): Malštové up. Rdvl. r.; Paberž-is pv. (Lnk. k.): pabéržé „vieta po beržu“; Purv-is pv., sln. (Skm. k.): pur̃ve „Šlapia vieta, paversmis“; Šlýn-is 1 pv., 1 a. ž. (Kaul. k., Agm. k.) šlýnas „dumblas, purvynas“.

Galūnè $-y s$

Rastas vienas dvejopos kilmès galūnès vedinys: Margavon-ys drv., pv. (Krk. k.): plg. margavone „toliau nuo sodybų esanti žeme““ plg. Margavõniai k. Rdvl. r.

Galūnè -os

Rasti 4 galūnès vediniai. Pvz.: Al̃gen-os a. ž. (Pp. k.): Algenis avd.; Atáug-os pv. (Pb. k.): atáugas „,antroji žolè, antrieji dobilai, atolas“; Súod-os a. ž. (Agm. k.): súodis „anglis, virtusi skrajojančia suodim“. 


\subsubsection{Priešdèliụ vediniai}

Rasti 35 priešdèlių vediniai. Dažnai sudarant vedinius su priešdèliais kinta ir vedinio galūnè. Priešdèlių vediniai smulkiau skirstomi pagal priešdèlį, jei yra pakitusi vedinio galūnè - ji atskiriama brūkšneliu.

Priešdèlis pa-

Rasta 19 priešdèlio vedinių. Pvz.: Pa-ąžuolỹne 2 a. ž. (Rdv. k., Žb. k.): ąžuolỹne „vieta, kur auga ąžuolai“; $\boldsymbol{P a - g r i n d o s ~ p v . , ~ d r . ~ ( A r . ~ k ) : ~ g r i n d a ̀ ~ „ r a ̨ s t u ̨ ~ k l o t a ~ v i e t a ; ~ g r i n d y s “ ; ~} \boldsymbol{P a}$ skirvain-ys pv. (Dk. k.): Skirvainis avd.; Pa-stárklizdis pv. (Jdp. k.): star̃klizdis „gandralizdis“; Pa-stìrčia pv. (Agm. k.): plg. stìrta „didelè sukrautų šiaudų, javų ar šieno krūva“; $\boldsymbol{P a - v e r ̂ k s m - i s ~ p v . ~ ( J d p . ~ k . ) : ~ V e r k s m e ́ ~ u p . ; ~ P a - z ̌ v y r i n c ̌ i u s ~ a . ~ z ̌ . ~ ( V l . ~ k . ) : ~ p l g . ~ z ̌ v y ̃ r i n a s ~ „ z ̌ v y r u o - ~}$ tas“, žveriñ̃̌ius „žvèrynas“.

Priešdèlis pri-

Rasti 3 priešdèlio vediniai. Pvz.: Pri- vart-é pv. (Gnd. k.): var̃tai „varstoma, kilnojama tvoros dalis"; Prì-vartis 1 pv., 1 šl. gn. (Vl. k., Šlk. k.): var̃tai. Vieno iš vedinių darybai panaudotas ne tik priešdèlis, bet ir priesaga: Pri-sodyb-ine a. ž. (Dvk. k.): sodýba „vieta, žemè apie namus su visais trobesiais“.

Priešdèlis $u \check{z}$ -

Rasta 13 priešdèlio vedinių. Pvz.: Už-asiklynis drv. (Kaul. k.): Asiklynis pv. Kaul. k.; 方cjkenď̌kelmin-is a. ž. (Bbr. k.): plg. kelmỹné „vieta, kur likę vien kelmai“; Už-kruoj-is pv. (Gnd. k.): plg. Krúoja up. Šl. r.; Už-kujalis drv. (Kaul. k.): Kujãlis avd.; Už-vézgis pv. (Antk. k): Vėzgis up. Rdvl. r.

\subsection{SUDĖTINIAI AGRONIMAI}

Iš viso rasti 88 sudètiniai agronimai. Juos galima skirstyti i kilmininkinius ir kvalifikacinius.

\subsubsection{Kilmininkiniai agronimai}

Rasti 75 kilmininkiniai agronimai. Juos galima skirstyti pagal pirmąji komponentą.

Pirmasis komponentas - toponimas.

Rasti 8 agronimai, kurių pirmasis komponentas - toponimas. Šiuos agronimus galima smulkiau skirstyti pagal toponimo rūši.

Hidronimai: Barškelio galas pv., drv. (Ar. k.): Bárškelis up. Rdvl. r.; Kutenos pievos pv. (Kut. k.): Kutenà up. Rdvl. r.; Rimúošès kalnas a. ž. (Mnk. k.): Rimúošè up. Rdvl. r.; Senosios Šakos laukas a. ž. (Rdv. k.): Šaka up. Rdvl. r.

Oikonimai: Amãlijos laukas a. ž. (Rdv. k.): Amãlija k. Rdvl. r.; Sedūnų pakrūmè pv. (An. vnk.): Sedúnai k. Rdvl. r.

Pirmasis komponentas - asmenvardis

Rasta 19 agronimų. Pvz.: Antano trakas pv. (Pšk. k.): Antãnas avd.; Bálnių marka pv. (Bk. k.): Balnỹs avd.; Liboniukès akmuo drv. (Kaul. k.): plg. Libónas avd.; Linkaičiu pabalys pv. (Ilg. k.): dgs. iš Linkáitis avd.; Mariùkès kelelis pv. (Lb. k.): plg. Marija avd.; Mélniko pieva pv. (Krauk. k.): Mélnikas avd.; Orvido bala pv. (Skn. k.): Órvidas avd.; Prãno pievẽlè pv. (Pp. k.): Prãnas avd.; Petro bala a. ž. (Srt. k.): Pẽtras avd.

Pirmasis komponentas - bendrinis daiktavardis

Rasti 44 agronimai, kurių pirmasis komponentas - bendrinis daiktavardis. Pvz.: Bùbo balà pv. (Šd. mst.): bùbas „toks apskritas daiktas; vaikų baidyklè, baubas“; Bajoru dalys a. ž. (Pr. k.): bajõras „privilegijuotas aukštesnio luomo žemvaldys“; Gaĩdžio lankà pv. (Klč. k.): gaidỹs „vištų patinas“; Kalnos galas drv. (Krk. k.): plg. kálnas; Kalvio dirvonai drv., pv. 
(Ar. k.): kálvis „kas verčiasi metalo kalimo amatu“; Kìsšio píeva pv. (Jdv. dv.): kiškis „graužikų šeimos laukinis gyvulèlis“; Nabašnýko balà a. ž. (Srt. k.): nabašnikas „lavonas“; Sillkiu upẽlis $\operatorname{sln}$. (Šlk. k.): siľke „nedidelè jūrų žuvis, papr. maistui vartojama sūdyta“; Šunies uodega a. ž. (Lb. k.): šuo „gyvulys, laikomas namams saugoti, medžioklei ir kt.“

Buvo rasti du kilmininkiniai agronimai, kurių vienas komponentas nėra aiškus. Pvz.: Palnẽko pašmákštelis a. ž. (Pž. k.): pašmakšt „braukšt, šmakšt, šmurkšt“; Polia Otvodokty a. ž. (Dvk. k.): plg. rus. поле (liet. laukas).

Aptariant kilmininkinius agronimus pagal pirmąji komponentą, buvo paminèti ne tik žemès plotų vardai, kurie vartojami tiesiogine prasme, bet ir tie, kurie vartojami metaforiškai, t. y. kurių antrasis komponentas reiškia objektą, nesusijusį su žemès plotais. Metaforiškai vartojamų kilmininkinių hidronimų antruoju komponentu dažniausiai eina žodžiai: kalnas (18), bala (7), upelis (6). Visi kiti agronimai - topografiniai. Jie pagal pirmąji komponentą skiriami ị vietovardinius, antroponiminius ir apeliatyvinius.

2.2.2. Kvalifikaciniai agronimai

Rasta 13 kvalifikacinių agronimų. Šie agronimai smulkiau skirstomi pagal pirmąji komponentą, kuriuo gali eiti ịvardžiuotinis būdvardis: Didžióji akmẽné drv. (Rml. k.); Didžióji lankà pv. (Klč. k.); Didžióji píeva 3 pv., 1 a. ž., pv. (Aukšt. k., Grž. k., Kaul. k., Žn. k.); Gražusis kalnelis 1 . (Brnč. k.); Žaliasis kalnelis a. ž. (Vbl. k.) arba paprastasis būdvardis: Geležìnes márgès l. (Šd. mst.); Kurtinis kalnelis a. ž. (Vbl. k.); Vidurinis laukas drv. (Lnk. k.).

Rasti 3 agronimai, kurių ypatybès reikšmę nusakantis būdvardis yra ne pirmasis, o antrasis komponentas. Pvz.: Plentovka didele pv. (Vsm. dv.): plg. pléntas; Plentovka maža pv. (Vsm. dv.): plg. pléntas; Upẽlis siauràsis pv. (Avž. k.).

\subsection{DŪRINIAI}

Iš viso rasti 147 dūriniai. Juos galima skirstyti pagal kalbos dalis, einančias dūrinio sandais.

\subsubsection{Dūriniai iš dviejų daiktavardžių}

Rasta 115 dūrinių. Juos galima skirstyti pagal pirmąji sandą.

Pirmasis sandas - augalo pavadinimas

Rasti du dariniai: Aglìn-bala pv. (Šd. mst.): plg. ẽglè, balà. Bérž-upis pv., gn. (Užp. k.): béržas, ùpis.

Pirmasis sandas - gyvūno pavadinimas

Rasti 4 dariniai. Pvz.: Katìn-bala a. ž., krm. (Lb. k.): kãtinas, balà; Dus-upỹs pv., up. (Avž. k.): plg. dūsià „toks vabalų būrio vabzdys, gyvenantis vandens telkiniuose“, ùpis; Vilk$\boldsymbol{a}$-kalnis d. ž. (Bt. k.): vil̃kas, kálnas; Viĩk-brada pv. (Kmrš. k.): vililkas, bradà „didelis purvas, klampus kelias, šlapia vieta“.

Pirmasis sandas - konkrečios ar abstrakčios reikšmės daiktavardis

Rasta 79 dariniai. Pvz.: Būd-vietis drv. (Miež. k.): būdà, vietà; Darž-gala pv. (Blt. k.): dar̃žas, gãlas; Degsn-y-balis pv. (Pvrt. k.): degsnỹs, balà; Dirv-o-galis a. ž. (Blt. k.): dirvà, gãlas; Ežér-kalnis pv., a. ž. (Vd. k.): ẽžeras, kálnas; Goj-ã-vietė a. ž. (Ald. k.): gõjus, vietà; Goj-a-vietès a. ž. (Jdp. k.): gõjus, vietà; Karv-è-bàla gn., pl. (Ksp. k.): kárvè, balà; Kiem-galis gn. (Žn. k.): kiẽmas, gãlas; Maskol-kalnis a. ž. (Pr. k.): maskõlius „caro kariuomenès kareivis“, kálnas; Obelýn-upis pv. (Šnr. k.): obelýnas, ùpé; Sidabr-a-pievè pv. (Bln. k.): sidãbras, píeva; Sèdiñ-galiai 1 drv., 1 a. ž. (Krk. k., Pž. k.): sédimas, gãlas; Sod-vietès drv. (Ar. k.): sõdas, vietà; Trak-a-pilvis a. ž. (Vl .k.): trãkas, pĩ̃vas; Trein-ù-galis a. ž., pv. (Pp. k.): treĩnas,

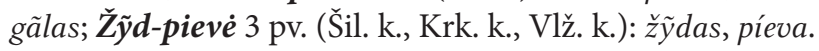


Pirmasis sandas - tikrinis daiktavardis

Rasta 30 dūrinių. Šiuos žemès plotų vardus galima smulkiau grupuoti pagal tikrinị daiktavardi.

Pirmasis sandas - asmenvardis, pvz.: Anuž-bala pv., b. (Pr. k.): Ãnužis avd., balà; Daniūn-bala l. (Pkln. k.): Daniúnas avd., balà; Jogmin-kelis a. ž. (Skm. k.): Jógminas avd., kẽlias; Mikol-balis a. ž. (Prš. k.): plg. Mikoláitis, Mýkolas avd., balà; Morkùn-pievis pv. (Šnr. k.): Morkúnas avd, píeva; Viñc-bala gn. (Žnr. k.): Viñcas avd. balà; Zigmant-upis pv. (Gnk. vnk.): Zìgmantas avd., ùpis.

Pirmasis sandas - vietovardis (2), pvz.: Dubýs-galis pv. (Žb. k.): Dubýsa up., gãlas; Raginèn-laukis pv. (Šd. mst.): Raginénai k. Rdvl. r., laũkas.

\subsubsection{Dariniai iš būdvardžio ir daiktavardžio}

Rasti 22 šios rūšies dūriniai. Pvz.: Aukšt-ã-trakis d. 1. (Vl. vnk.): áukštas, trãkas; Aũ ǩšt-ežéel. (Šd. mst.): aukštà, ežia „rèžio ar lauko riba“; Didž-laukis a. ž. (Mnk. k.): didžiùlis, laũkas; Júod-kalnis a. ž. (Mrgv. dv.): júodas, kálnas; Naũj-a-laukis d. 1. (Šnr. k.): naũjas, laũkas; Raudón-kalnis 5 a. ž., 1 l. (Grž. k., Kat. k., Mnk. k., Šd. mst., Šlk. k., Vd. k.): raudónas, kálnas; Saũs-dvaris d. ž. (Mž. k.): saũsas, dvãras; Šveñt-laukis a. ž. (Jdp. k.): šveñtas, laũkas.

\subsubsection{Dariniai iš veiksmažodžio ir daiktavardžio}

Rasti 6 tokie dūriniai. Pvz.: Baudž-a-balis pv., b. (Pvrt. k.): baũsti, balà; Daũž-laukis drv. (Jkn. k.): daũžti, laũkas; Gaud-líeknis pv. (Vlš. k.): gaũsti, líeknas; Grauž-galys pv. (Nkr. k.): gráužti, balà; Griáuž-bala pv., b., d. ž. (Ldš. k.): griáužti žr. gráužti, balà; Kviký-bala pv. (Šd. mst.): kvikýti, balà.

\subsubsection{Dariniai iš skaitvardžio ir daiktavardžio}

Rastas vienas dūrinys: Peñk-pūrè a. ž. (Pbrž. k.): penkì, púras „javų kiekio matas“.

\subsubsection{Kiti dūriniai}

Iš prielinksnio ir daiktavardžio

Rasti 3 dariniai. Pvz.: Prie-pridotkai a. ž. (Kat. k.): pridõtkas „pridètinis žemès sklypas“;

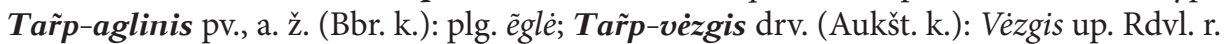

Aptariant dūrinius pagal jų sandus, buvo paminèti žemės plotų vardai, kurie vartojami tiesiogine ir metaforine prasme. Rasti metaforiniai agronimai, kurių antruoju sandu dažniausiai eina žodžiai: bala (43), upe (13), kalnas (14), dvaras (3), miškas (3). Metaforiniai agronimai sudaro $75,5 \%$ visų dūrinių.

Dūrinius galima skirstyti ne tik pagal kalbos dalis, einančias agronimo sandais, bet ir pagal sandų jungimo būdus. Dalis $(25,8 \%)$ rastų dūrinių turi jungiamuosius balsius $(a, i a$, $\dot{e},(i) o, u, \bar{u})$.

\subsection{PRIELINKSNINIAI AGRONIMAI}

Prielinksninių agronimų, kaip ir kitų grupių toponimų, randama gana mažai. Jie kalbos vartosenoje išsilaiko trumpai, yra linkę kisti ir virsti î priešdèlinius arba pirminius agronimus.

Rasti 2 agronimai, sudaryti su prielinksniu po. Vienas agronimas padarytas iš prielinksnio ir augalo pavadinimo: Põ pušies a. ž. (Ppl. k.): põ ir pušis, kitas - iš prielinksnio ir oikonimo: Põ Baisógala a. ž. (Vl. dv.): põ ir Baisógala. 


\section{IŠVADOS}

1. Išanalizavus Baisogalos, Radviliškio ir Šeduvos valsčių Žemès vardų anketas, buvo rasti 1185 (936 neskaitant pasikartojančių) agronimai: pievų, laukų, dirbamų žemių, ganyklų ir kt. vardai. Atlikta darybinè analizė atskleidè, kad daugiau užrašyta antrinių agronimų, turinčių derivacinių požymių (57,7 \%). Apie pusę (54,6 \%) antrinių agronimų grupès sudaro vediniai. Smulkesnè vardų klasifikacija rodo, kad daugumą jų sudaro priesagų vediniai $(78,6 \%)$, kurių darybai pavartotos 29 priesagos. Mažesnes vedinių grupes sudaro galūnių $(9,5 \%)$ ir priešdèlių $(11,9 \%)$ vediniai. Galūnių vedinių darybai panaudotos 7 galūnès; produktyvumu išsiskiria su -is ir -(i)ai galūnèmis sudaryti vediniai. Priešdèlių vedinių darybai panaudoti tik 3 priešdèliai: $p a-$, $p r i-, u z ̌-;$ populiariausi su priešdèliu $p a$ - sudaryti vediniai. Mažesnè antrinių agronimų grupè yra dūriniai (29,1\%). Dūrinių grupèje produktyviausi dūriniai iš dviejų daiktavardžių (73,3\%), kurių pirmasis sandas - konkrečios ar abstrakčios reikšmès daiktavardis (69,6 \%). Mažiausiai rasta sudètinių vardų (16,3\%). Šioje grupejje populiariausi kilmininkiniai agronimai $(85,2 \%)$, kurių pirmasis komponentas - bendrinis daiktavardis $(58,7 \%)$.

2. Rasti 364 (38,9 \%) pirminiai agronimai. Analizè rodo, kad absoliučią jų daugumą sudaro daiktavardiniai agronimai (95,9 \%). Jų pamatiniais žodžiais eina fiziografiniai terminai, įvairių vietų pavadinimai, kiti toponimai, asmenvardžiai, augalų ar gyvūnų pavadinimai ir įvairūs konkrečios ar abstrakčios reikšmès daiktavardžiai. Šioje grupejje vyrauja agronimai, kurių pamatu eina vietų pavadinimai.

3. Baisogalos, Radviliškio ir Šeduvos valsčių agronimų analizė rodo, kad dauguma vardų yra beveik ar visai aiškios darybos. Galimi dvejopos darybos agronimai (kai šalia pagrindinio pamatinio žodžio nurodomas ir antras) tirtoje medžiagoje sudaro tik 3,8 \%.

4. Nesant duomenų apie dar keturių - Grinkiškio, Pašušvio, Sidabravo ir Šiaulėnų - Radviliškio rajono valsčių agronimus, straipsnyje nebuvo galimybės apžvelgti visam rajonui būdingų agronimų darybos tendencijų. Ateityje numatoma visų Radviliškio rajono agronimų darybos analizè papildys šiame straipsnyje pateiktus duomenis, suteiks galimybę juos lyginti su kitų rajonų agronimais, atskleisti būdingus agronimų darybos bruožus.

Santrumpos

Agm. - Augmènai

Ald. - Aldoniškis

Ar. - Arimaičiai

Aukšt. - Aukštelkai (ir dv.)

Bbr. - Bebrujai

Brnč. - Bernočiai

Brz. - Berezinos (dv.)

Bsg - Baisogalos dv. ir frm.

Bt. - Butènai

Dk. - Daukučiai

Dkn. - Dakniškių (dv.)

Drg. - Dargužiai

Dvk. - Daveikiai

Gmb. - Gimbogala

Gnk. - Gankiai

Grb. - Grubai 
Grn. - Girvalakiai

Grž. - Gražioniai (ir dv.)

Gv. - Gavėniškiai

Ilg. - Ilguočiai

Jdp - Juodupiai

Jdv. - Jadvimpolio (dv.)

Jkn. - Jukniškiai

Jnk. - Jankūnai

Jrb. - Jurbarkas

Kat. - Katiškiai

Kaul. - Kauliniai

Kbl. - Kabliai

Klb. - Kleboniškiai

Klč. - Kliučiai

Kmr. - Kemerai

Kmrš. - Komariškiai

Knv. - Kaneivaičiai

Krauk. - Kraukenai

Krč. - Karčiamos

Krk. - Kurkliai

Krkl. - Kurklaičių (dv.)

Ksp. - Kaspariškiai

Kut. - Kutiškiai

Lb. - Labučiai

Ldš. - Liaudiškiai

Lp. - Lopai

Lnk. - Linkaičiai

Lnšk. - Liuniškiai

Ltk. - Liutkiškiai

Miež. - Miežaičiai

Mnk. - Mankiškiai

Mrgv. - Margavonių (dv.)

Mrl. - Muralynè

Mtk. - Matkaičių (dv.)

Mž. - Mažaičiai

Nj. - Naujasodis

Nkr. - Nekrašūnai

Pb. - Paobeliai

Pbrž. - Paberžèliai

Pkln. - Pakalniškiai

Pln. - Palonai (ir dv.)

Pp. - Puipiai

Ppl. - Papaliai

Pr. - Prastavoriai

Pšk. - Pašakiai

Pšl. - Pašlapèlè 
Pvrt. - Pavartyčiai

Pž. - Paežeriai

Rdv. - Radviloniai

Rk. - Rukaičiai

Rml. - Ramulènų (dv.)

Sd. - Sedūnai

Skm. - Skemiai

Skn. - Skynimiškiai

Skr. - Skirjočiai

Slb. - Slabudka

Slk. - Sliekiai

Srt. - Sirutiškių (dv.)

Šd. - Šeduva

Šil. - Šilaliai

Šlk. - Šileikoniai

Šnk. - Šnikoniai

Šnr. - Šniūraičiai

Ššn. - Šašènai

Taut. - Tautiškiai

Už. - Užuožeriai (ir dv.)

Užp. - Užpurviai

Vbl. - Vabalių (dv.)

Vd. - Vaiduloniai

Vl. - Valatkoniai (ir dv.)

Vlg. - Vilgirdaičiai (ir dv.)

Vlk. - Vilaikiai (ir dv.)

Vlš. - Vališkiai

Vlž. - Velžiai

Vn. - Vainiūnai

Vnt. - Vantainiai

Vntn. - Vantainèliai

Vrš. - Vèriškiai

Vrt. - Vertimai

Vsm. - Vismantai

Vš. - Viešvile

Vž. - Vaižgiai

Žb. - Žibartai

Žn. - Žinènai

Žr. - Žironai

a. ž. - ariama žemé

b. - bala

buv. rž. - buvę rèžiai

drv. - dirva

drž. - daržas

dv. - dvaras

d. ž. - dirbama žemé 


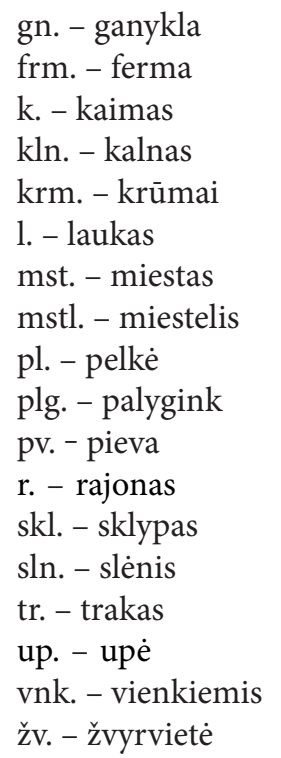

Gauta 20150329

Priimta 20160914

\section{LITERATŪRA}

[1] BILKIS, Laimutis. Lietuviu helonimu daryba. Priesaginiai ir priesagetieji helonimai. Vilnius, 2008.

[2] BARTKUTĖ, Nerija. Joniškio rajono teritorijos toponimija: daryba ir raidos polinkiai. Daktaro disertacija. Šiauliai, 2008.

[3] ENDZELYTĖ, Renata. Šiaurés vidurio Lietuvos vietovardžiai. Daktaro disertacija. Kaunas, 2005.

[4] ENDZELYTĖ, Renata. Šiaurès vidurio Lietuvos agronimai. Vārds un tā pētǐšanas aspekti. Rakstu krājums, 2004, 8, p. 80-89.

[5] Dabartines lietuviu kalbos žodynas. Prieiga per internetą: http://dz.lki.lt/

[6] Gamtos katalogas. Prieiga per internetą: http://ezerai.vilnius21.lt/

[7] KAČINAITĖ, Dalia. Priesaginés darybos lietuviu oronimai. Daktaro disertacija. Vilnius, 2009.

[8] Kirčiavimo žodynas. Prieiga per internetą: http://donelaitis.vdu.lt/main.php?id=4\&nr=9_1

[9] KUZAVINIS, Kazys; SAVUKYNAS, Bronys. Lietuviu vardų kilmes žodynas. Vilnius, 2003.

[10] LEMCHENAS, Chackelis; MASAITIS, Jonas. Rusu-lietuviu kalbu žodynas. Vilnius, 2003.

[11] Lietuvos vietovardžiu geoinformacinés duomenu bazès [žiūrèta 201404 10]. Prieiga per internetą: http://lvvgdb.lki.lt/vietovardziai/?pid=6.

[12] Lietuvių kalbos etimologinis žodynas. Prieiga per internetą: http://etimologija.baltnexus.lt/

[13] Lietuviu kalbos žodynas. Prieiga per internetą: http://www.lkz.lt/

[14] Lietuviu pavardžiu žodynas. T. 1 (A-K). Vilnius, 1985.

[15] Lietuviu pavardžių žodynas. T. 2 (L-Ž). Vilnius, 1989.

[16] MICKIENĖ, Ilona. Telšių rajono toponimu daryba. Daktaro disertacija. Kaunas, 2001.

[17] MICKIENĖ, Ilona. Dèl agronimų darybos. Kalbų studijos. Nr. 8. Kaunas, 2006, p. 27-30.

[18] RAZMUKAITE், Marija. Lietuvos priesaginiai oikonimai. Daktaro disertacija. Vilnius, 1998.

[19] SVIDERSKIENĖ, Dalia. Acta Linguistica Lithuanica. Marijampoles apskrities asmenvardinès 
kilmés agronimy darybos bruožai, 2010, LXII-LXIII. p. 97-127.

[20] SVIDERSKIENĖ, Dalia. Dèl Marijampolès apskrities agronimų - priesagos -in- vedinių. Acta Linguistica Lithuanica. Lietuviu kalbotyros klausimai, 2012, 66, p. 81-98.

[21] VAITKEVIČIÜTĖ, Valerija. Didysis lenkų-lietuvių kalbu žodynas. T. 1-2. Vilnius, 2003.

[22] VANAGAS, Aleksandras. Lietuvių hidronimų etimologinis žodynas. Vilnius, 1981.

[23] VANAGAS, Aleksandras. Lietuvių hidronimų semantika. Lietuviu onomastikos tyrinèjimai. Lietuviu kalbotyros klausimai, 1981, XXI, p. 4-153.

[24] VANAGAS, Aleksandras. Lietuvos TSR hidronimu daryba. Vilnius, 1970.

[25] VANAGAS, Aleksandras. Lietuvos miestu vardai. Vilnius, 1996.

[26] Vietovardžiu kirčiavimo žodynas. Vilnius, 1994.

[27] Vietovardžiu žodynas. T. 1 (A-B). Vilnius, 2007.

[28] „Versmès“ leidyklos internetinis puslapis [žiūrèta 2014 04 10]. Prieiga per internetą: http:// www.versme.lt/seduva_kaimai.htm; http://www.versme.lt/bais_kaimai.htm.

ILONA MICKIENĖ, SANDRA GAILIŪNAITÉ

\title{
Agronyms of the Radviliškis District: trends in the formation of agronyms in the rural districts of Baisogala, Radviliškis, and Šeduva
}

\begin{abstract}
Summary
Toponyms of Lithuania have been investigated by many linguists. Unfortunately, not all toponym classes are investigated as well as others. This work is one of the very few that deals with agronyms.

The objective of this work is to investigate the formation of agronyms in the rural districts of Baisogala, Radviliškis, and Šeduva. The following tasks have been set to achieve this goal: to collect agronyms from authentic pre-war Field-Name questionnaires which are stored at the Department of Onomastics of the Institute of the Lithuanian Language; to analyze the collected agronyms using the grammatical-structural classification proposed by Aleksandras Vanagas; to define the most productive types of formation. Descriptive, structural, quantitative and document analysis methods were used in this paper.

In total, 936 agronyms were collected. The agronyms are divided into primary and secondary names. The analysis shows that there are more secondary names (57.7\%). Secondary names are divided into derivatives (54.6\%), compounds, and composite names. The first group is divided into suffix (78.6\%), prefix (11.9\%), and flexion (9.5\%) derivatives. The second group is divided into names that are made from two nouns $(73.3 \%)$, a noun and an adjective (14\%), a verb and a noun (3.8\%), a preposition and a noun $(1.9 \%)$, and a numeral and a noun $(0.6 \%)$. Finally, the third group is divided into names which are the genitive case of nouns (85.2\%) and qualificative names $(14.8 \%)$.

Primary names (38.9\%) are less popular than secondary ones. Primary names are divided into groups in which the names are made from nouns $(95.9 \%)$ and from adjectives (4.1\%).
\end{abstract}

Keywords: agronym, derivational analysis, toponym 